Annals of Plant Sciences

ISSN: 2287-688X

OPEN ACCESS

www.annalsofplantsciences.com

Research Article

\title{
Geranium robertianum L. (Geraniaceae): A new record for the \\ flora of Iraq.
}

Sirwan Hassan Salih*

Biology Department, College of Education, University of Garmian, Iraq-Kurdistan.

Received: 01-07-2018; Revised: 11-08-2018; Accepted: 27-09-2018

\begin{abstract}
Plant specimens were collected during a fieldtrips near Derbandikhan city (Sulaimani province) in Spring 2016, is added to the other 10 species of this genus previously reported from Iraq. Gross morphology of all plant parts was investigated comparatively, description and detailed figures are given. The geographical distribution is mapped. Previous checklists and studies were checked, to confirm and prove that this species is a new record for the flora of Iraq. A comprehensive study of literatures, herbaria and preceding checklists has been conducted.
\end{abstract}

Keywords: Plant Taxonomy, Geraniaceae, Geranium, New record, Iraq (Kurdistan Region).

\section{Introduction}

Geraniaceae is a cosmopolitan family in their distribution in temperate or warm temperate and subtropical of the northern and southern hemisphere (Lawrence, 1951). Geranium L. (Cranes Bill) genus belongs to the tribe Geranieae of the family Geraniaceae (Boissier, 1867) and comprises about 350 species distributed in temperate and tropical alpine regions in the world (Lawrence, 1951 and Aedo et al., 2005). Knuth (1912) published his monograph on Geranium, recognized 260 species, and over 423 are currently accepted, Reich (1890) proposes the first classification for the entire genus, which he divided into 10 sections. Knuth (1903) recognized 12 sections and later, in his monograph (Knuth, 1912) distinguished 30 of them. Subsequently, Knuth (1931) added 2 more. Knuth from 1912-1933 scheme 328 sections for the genus have been questioned by numerous authors (Warberg 1938a, 1938b, Tokarski 1972); Geranium is divided into the subgenera Geranium, Erodioidea and Robertium (Aedo et al., 1998); Considering only type of fruit discharge, Yeo (1984, 1990) divided subg. Geranium into 3 sections, section Geranium is a widespread group, absent only in tropical lowlands.

According to the floras and previous taxonomic studies this genus is represented by 10 species in Iraq (Salih, 2009), 38 species in Turkey (Davis et al., 1982) and 47 species in Iran (Rechinger, 1964). 14 spp. in Syria, Palestine

\footnotetext{
${ }^{*}$ Corresponding Author:

Prof. Sirwan Hassan Salih,

President Of Garmian University

PhD in Biology - Botany- Plant Taxonomy

Kurdistan Region-Iraq

Garmian-Kalar, Iraq.

E-mail: herash1966@yahoo.com
}

and Sinai (Post, 1932) and 7 spp. in Egypt (Tackholm, 1974). Locally In Iraq there are previous works and checklists each indicated to the numbers and distribution of the Geranium species as Handel Mazzetti (1910) 1 species, Nabelek (1923) 2 spp, Guest (1933) m 4 spp., Zohary (1946) 6 spp, Blacklock (1948) 7 spp., Al-Rawi (1964) check listed 9 spp., Rechinger in flora of lowland Iraq (1964) noted to 4 spp., Rechinger in flora Iranica (1972) listed 10 species distributed in Iraq, Chacravarty (1976) 9 spp., Khalaf (1980) recorded 7 spp. distributed on Sinjar mountains, Faris (1983) recorded 5 spp. distributed on Peramagroon mountains and recently Salih (2009) determined $10 \mathrm{spp}$. in Iraq.

\section{Materials and Methods}

Specimens of Geranium robertianum were collected during the spring of 2016 in Derbandikhan city (Sulaimani provinceNortheast Iraq) MSU district close to Derbandikhan Lake (Altitude: 495m, 356'39”N $45^{\circ} 40^{\prime} 59^{\prime \prime} \mathrm{E}$ ). Materials which depended as data for this study are herbarial specimens of Iraqi major herbaria Baghdad, National herbarium of Iraq (BAG), Baghdad-university herbarium, college of Science (BUH), Arbil-University of Salahaddin, College of Science (AUH) and Baghdad-College of Agriculture (BAH)\}, field trips, studies and checklists aforementioned and some Floras such as: Flora of Lowland of 
Iraq Rechinger (1964); Flora Iranica Rechinger (1964); Flora of Turkey Davis et al., (1982). Geographical distribution was made by aid of prepared maps (fig. 1), the species was photographed in their natural habitats (fig. 2, 3). Microcharacters were measured with aid of a compound microscope (Siezz) and dissecting microscope (Olympus). Pollen grains were prepared for light microscopy (LM) by using the standard method described by Erdtman (1969), pollens were investigated by Seizz microscope, under E40x, E100x with 10x eyepiece and photographed (fig. 4) by digital camera (SONY, 3x, 13.6 Megapixels).

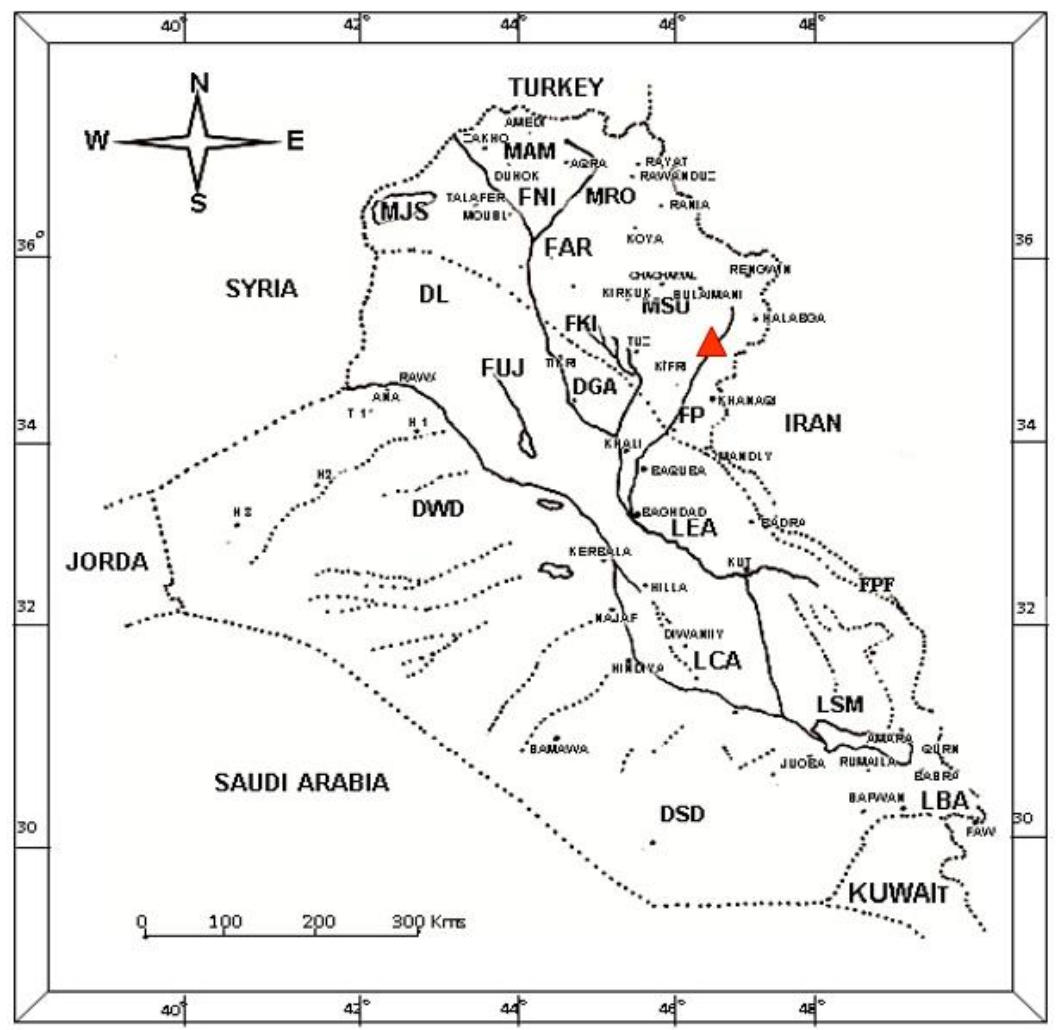

Figure 1. Distribution map of the Geranium robertianum $(\Delta)$ with physiographic regions and districts of Iraq.

Physiographic regions and districts of Iraq.

M - MOUNTAIN REGION
MAM - Amadiya District
MRO - Rowanduz District
MSU - Sulaimani District
MJS - Jabal Singar District
D - LOWER PLATEAU REGION
DLJ - Lower Jaziera District
DGA- Ghurfa - Adhaim District
DWD - Western Desert District
DSD- Southern Desert District

F - UPPER PLAINS AND FOOTHILLS REGION

FUJ- Upper Jaziera District

FNI- Nieneveh District

FAR-Arbil District

FKI- Kirkuk District

FPF- Persian District

L - LOWER MESOPOTAMIAN REGIO

LEA- Eastern Alluvial Plain District

LCA- Central Alluvial Plain District

LSM- Southern Marsh District

LBA- Basra Estuarine District

\section{Results and Discussion}

Geranium robertianum L., Sp. Pl. 681 (1753).

Edgew. \& Hook. F. in Hook. F., Fl. Brit. Ind. 1:432.1884; Knuth, l.c. 64; Collett, l.c.; Blatter, l.c.; Boiss., Fl. Or. 1:883.1867; Schischkin, l.c. 35; Schonbeck-Temesy in Rech. F., Fl. Iran. 69:37.1970; Ghafoor, l.c. 44.

Synonym:. Geranium eriophorum H. Lév.
Distribution: N. America, Canary Islands, C. \& S. Europe, Turkey, Iran, Caucasus, Siberia, Himalayas. Japan, Kazakhstan, Korea, Kyrgyzstan, Nepal, Pakistan, Russia, Tajikistan, Turkmenistan, Uzbekistan; Africa, W Asia, Europe.

Type: Described from N. Europe, Herb. Cliff. (BM); H.G. LINN. 858/70. 
Phenology and Ecology: Flowering in April, rocky soils.

Altitude: $480-500 \mathrm{~m}$.

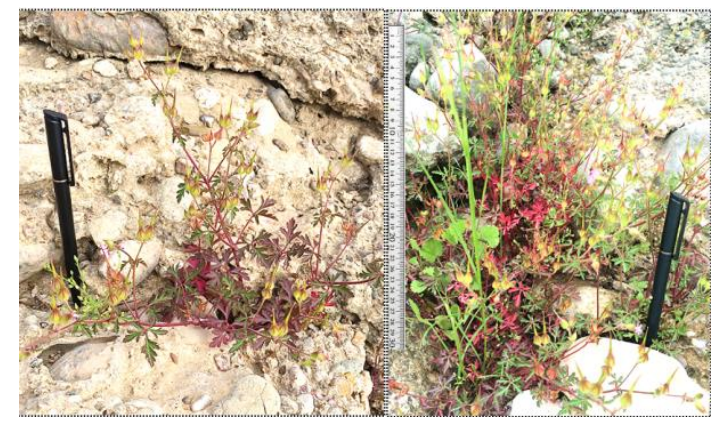

Figure 3. G. robertianum in their natural habitat

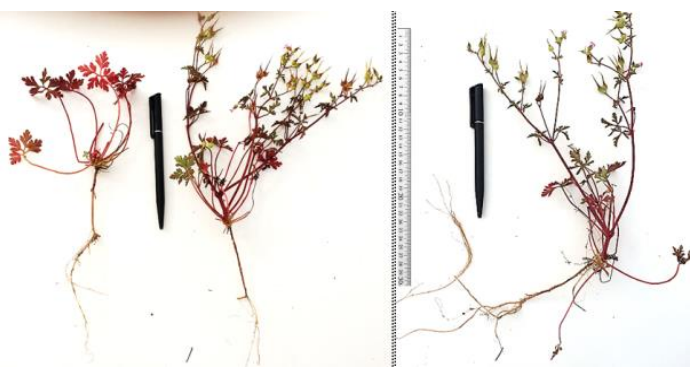

Figure 4. Herbarial specimens of $G$. robertianum

Figure 5. Aerial parts of G. robertianum

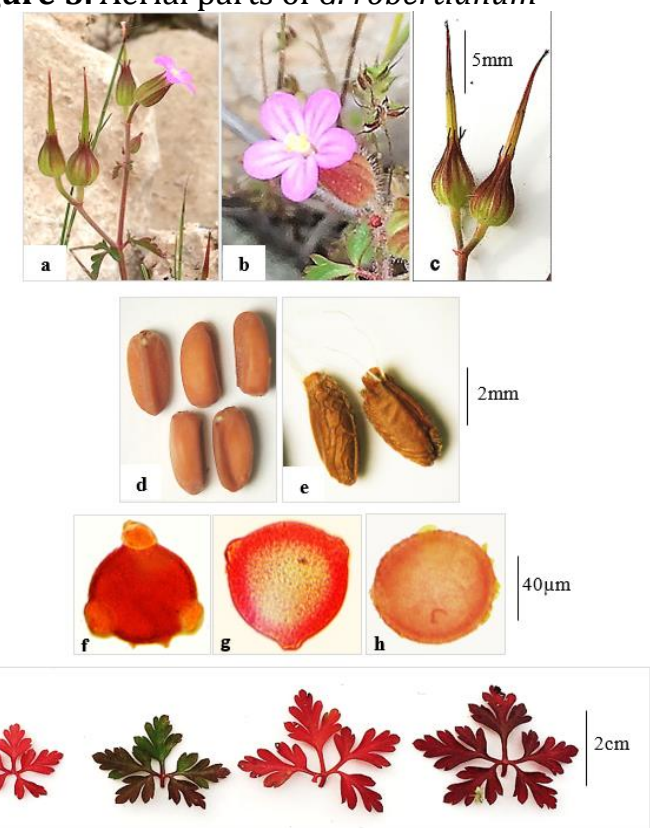

a, inflorescence; b, flower; c, fruits; d, seeds;

e, mericarp; f, g, pollens (polar view); h, pollens (equatorial view); i, leaves

Annual herbs, tap root, $10-45 \mathrm{~cm}$; stem branched (usually at base), often reddish to purple; leaves opposite, stipulate, petiolate, pedately trisect to the base, $2-5 \times 2-7 \mathrm{~cm}$; segments $3+2$ subsegments, $2-5 \times 1-4 \mathrm{~cm}$, long eglandular hairs, deeply pinnatifid into obtusely obulated divisions; petiole of basal leaves $1-6.5 \mathrm{~cm}$ long, of cauline leaves $2-18 \mathrm{~cm}$, long pilose; stipules $2.5 \times 1.3-3 \mathrm{~mm}$, long pilose; peduncles 2-flowered, glandular $2-9 \mathrm{~cm}$, short pilose and long glandular hairs; pedicles 2-116 $\mathrm{mm}$, pilose with long glandular hairs; bracts 1$2 \times 0.4-1 \mathrm{~mm}$, long and short pilose hairs. Flowers terminal, hypogynous, actinomorphic, pentamerose; sepals $5,3-7 \times$ x 1.5-4mm, glandular hairs, awn 1-4mm; petals 5.5-13 x 2$5 \mathrm{~mm}$, apex obtuse, 3-nerved, limb obovate, tapering towards the base purplish pink; stamens 10, usually in 2 whorls, outer whorl opposite to petals (obdiplostemonous), inner whorl opposite with sepals, all facing to toward the gynoecium (intrors) help to selfpollination; anther 10 , outline oblong, oblate and hemispherical, longitudinally dehiscence, 0.5-0.8mm; filaments linear with expanded base part and an abruptly narrowed above, glabrous, 5-0.5mm, versatile, nectaries 5, hemispheric, glabrous; pistils 1 , compound, 5 syncarpous; ovary superior, 5 lobed, locules5, 1.2-1.5mm; styles 5, 2.5-4.6mm, pilose, united, adhering to the ovarian beak and the basal portion recurving elastically; stigma 5, 0.6$1.4 \mathrm{~mm}$, ligulate or arm shaped; fruit's beak 10$15 \mathrm{~mm}$ long; mericarp 1-3x1-1.8mm, 2-3 prominent transversely ridged above the fewer reticulate ridge below, glabrous, brownish yellow; seeds smooth, 1.2-2.4x1-1.7mm, elliptic-oblong, brown or brownish yellow, umbo slightly projecting, black. Pollens orange to brownish yellow, $35-92 \mu \mathrm{m}$, polar axis 55$80 \mu \mathrm{m}$ diameter (triangle), equatorial axis 48$65 \mu \mathrm{m}$ diameter (circular to ovate), pollen surface area (P. a. length $\times$ E. a. length) $72 \times 65=$ $4680 \mu \mathrm{m}$.

In accordance to the results and reviewing preceding studies, checklists and checking the herbarial specimens of the major Iraqi herbaria (aforementioned) showed that this species is a new record for the flora of Iraq, the most recent taxonomic study of the genus Geranium in Iraq Salih (2009) does not refer to its presence in Iraq as well as there are more than 10 published checklists of Iraqi plants with flora of Iraq from 1910 to 1980, all of these did not reported the existence of this species. During the verification of the lists and herbarial specimens (Iraqi herbaria), the researcher confirmed that this species not previously recorded in Iraq and it haven't specimens in Iraqi and non-Iraqi herbaria therefore is regarded a new for Iraq. 
The species was found on the banks of Derbandikan Lake (495m altitude) in a humid environment among the rocks and directly exposed to sunlight with associated herbaceous plants as plants of family Poaceae and Asteraceae were spread high density in a limited geographical area. The results showed a similarity between the studied species and $G$. purperium with clear differences (table 1), the leaves of $G$. purperium are larger and more division than in $G$. robertianum, in general the flower are larger in $G$. robertianum and the petals are twice in length also the differences in the type and density of trichoms that covering the aerial plant parts, cytologicaly there are difference in chromosome number separates $G$. robertianum $(2 \mathrm{n}=64)$ from $G$. purperium (2n=32) Davis et al., (1982).

Table 1. Differences between $G$. robertianum and G. purperium

\begin{tabular}{ccc}
\hline Plant parts & G. robertianum & G. purperium \\
\hline Leaves size & $2-5 \times 2-7 \mathrm{~cm}$ & $3-7 \times 5-10 \mathrm{~cm}$ \\
Petals size & $5.5-13 \times 2-5 \mathrm{~mm}$ & $4-9 \times 3-4 \mathrm{~mm}$ \\
Cytology & $2 \mathrm{n}=64$ & $2 \mathrm{n}=32$ \\
\hline
\end{tabular}

\section{Conclusion}

The results of this study showed new record of the flora of Iraq, this new record species is very similar morphologically to the species Geranium purpurium, which leads to confusion between these two species so it requires accurate genetic studies to separate them.

\section{Acknowledgement}

The author would like to thank the Head and staff of Biology department in Faculty of Education (Garmian University) and college of Education (Tekret University) for their helping and providing laboratories.

\section{References}

1. Aedo C, et al., World checklist of Geranium L. (Geraniaceae). Madrid. Espana. 1998, 242.

2. Aedo $\mathrm{C}$, et al., Taxonomic revision of Geranium Sect. Dissecta.(Geraniaceae). Madrid. Espana. 2005, 534-558.

3. Al-Rawi A, Wild plants of Iraq with their distribution, Tech. Bull.14. dir. of Agr. Res. Proj. Ministry of Agriculture. Government press. 1964, 232.

4. Blakelock RA, The Rostum Herbaria, Iraq. Part 1. Systematic list. 1948, 408-409.
5. Boissier EP, Flora Orientalis. Vol 1, 1867, 869-884.

6. Chakravarty HL, Plant wealth of Iraq. Min. Agr. of Iraq, Vol. 1, 1976, 507.

7. Davis PH, Flora Turkey, Edinburgh. Great Britain, vol. 2, 1982, 450-487.

8. Erdtman G, Handbook of Palynology, 1969, $\mathrm{p}: 48,313$.

9. Faris YS, Vascular plants of Peramagroon Mountain (Iraqi Kurdistan region). MSc. Theses, 1983, 70-74.

10.Guest E, Notes on plant and plant products will their colloquial names in Iraq., Baghdad, the governments press, Bull. 27, 1933, p:13, 37.

11. Handlel-Mazzatti HV, Die Vegetations Varhaltnisse von Mesopotamian und Kurdistan, Vein. 191, 6-13.

12. Khalaf MK, Vascular plants of Sinjar Mountain. MSc. Theses,980, 170-74.

13. Knuth R, Über die geographische Verbreitung und die Anpassung serscheinungen der Gattung Geranium im Verhältnis zu ihrer systematischen Gleiderung. Bot. Jahrb. Syst., 1903, 190-230.

14. Knuth R, Geraniaceae in A. Engler (ed), A. Das Pflanzenreich IV-129, 1912, 1-640.

15. Knuth R, Geraniaceae. In: A. Engler and H. Harms (ed). Die natrülichen Pflanzenfamilien, ed. 2, 19a. 1931, 43-66.

16. Lawrence GH, Taxonomy of Vascular Plants. The Macmillan. Co. New York, 1951, 828.

17. Nabelek FR, Iter Turcico-Perrsicum. Pars 1. Plantarum collectarum mnumeratio,1923, 57-59.

18. Post GE, Flora Syria, Palestine and Sinai: vol. 1. Amer. Univ. of Beirut, 1932, 254-258.

19. Rechinger KH, Flora of Lowland Iraq, 1964, 389-398.

20. Rechinger KH, Flora Iranica, Akadimische Druck-u.Verlagsanstalt. Graz-Austria, 98, 1972, 1-67. 
21. Reiche K, Geraniaceae. IN: a. Engler and K. Prantl (eds.), Die Natürlichen Pflanzenfamilien. Vol. 3, 1890, 1-14.

22. Salih SH, A Systematic Study of the of the Genera Biebersteinia Stephan and Geranium L. (Geraniaceae) in Iraqi Kurdistan Region. (PhD. thesis). Sulaimani University. College of science, 2009.

23. Tackholm V, Students Flora of Egypt. 2nd edit. Cairo University Cooperative printing Co. Beirut, 1974, 295-299.

24. Warburg EF, Taxonomy and Relationship in the Geraniales in the light of their cytology. New. Phytol, 37, 1938a,130-159.

25. Warburg EF, Taxonomy and relationship in the Geraniales in the light of their cytology. 2. New, phytol, 37, 1938b,189-210.
26. Yeo PF, Fruit-discharge-type in Geranium (Geraniaceae): it's used in Classification and its evolutionary implication. Bot. J. Linn. Soc, 1984, pp: 1-36.

27.Yeo PF, The classification of Geraniaceae. In: P. Vorster (ed.), Proceeding of the international Geraniaceae symposium. Stellenbosch, 1990, 1-22.

28.Zohary M, The Flora of Iraq and its phytogeographical subdivisions. Iraq Dept. Agr. Bull. 3, 1946, 96-97.

\section{Cite this article as:}

Sirwan Hassan Salih. Geranium robertianum L. (Geraniaceae) A New Record Of The Flora Of Iraq. Annals of Plant Sciences 7.10 (2018) pp. 2441-2445.

do $\mathrm{http://dx.doi.org/10.21746/aps.2018.7.10.3}$

Source of support: Head and staff of Biology department in Faculty of Education (Garmian University) and College of Education (Tekret University).

\section{Conflict of interest: Nil.}

